\title{
Hvilket europæisk land har siden 1998 haft størst vækst?
}

Debat mellem Flemming Rose og Søren Liborius

Den 15. oktober skrev Flemming Rose et indlæg i Berlingske med henblik på at udfordre en udbredt opfattelse af, at Rusland står på randen af den økonomiske afgrund. Rose tager udgangspunkt $i$ et interview $i$ the Economist med præsident Obama, der kommenterede Ruslands økonomiske situation og demografi tilbage i 2014. Indlægget gav anledning til en del polemik ansporet af en enkelt tvivlsom kildehenvisning, som dog ikke underminerede den centrale pointe - denne polemik er ikke genstand for nærværende udveksling. Hensigten er at få en bedre forståelse af Ruslands aktuelle økonomiske situation.

Her følger først Flemming Roses indlæg i Berlingske, derpå en udveksling af kommentarer mellem Søren Liborius og Flemming Rose, skrevet til Udenrigs.
Flemming Rose

(Indlæg i Berlingske 15. oktober 2018) Der var fire faktuelle fejl i fire sætninger om Rusland, da Barack Obama blev interviewet i 2014. Det er et godt eksempel på, hvordan vi i Vesten ser på Rusland og understreger, at kvantificerbar tænkning, data og statistik er nøglen til at frigøre sig fra fordomme, hvis man ønsker at forstå verden.

I efteråret 2014 blev USA's præsident Barack Obama i et interview spurgt, hvordan han så på truslen fra Rusland, og hvordan den skulle håndteres. Obama opfordrede til at bevare et vist perspektiv og ikke overdrive. Derpå forklarede han hvorfor: "Rusland producerer ikke noget. Immigranter har ikke travlt med at komme til Moskva for at søge muligheder. Russiske mænds forventede levealder er omkring 60 år, og befolkningen skrumper."

Flemming Rose er forfatter, journalist og nu seniorforsker ved den amerikanske tænketank Cato Institute. Han er tidligere kultur- og udlandsredaktør på Morgenavisen Jyllands-Posten; Søren Liborius er cand.mag. i øststatskundskab, fhv. presse- og informationschef, EU's delegation i Rusland. 
1. På det tidspunkt var Rusland efter USA ifølge FN det land i verden, som havde den største indvandring (det passede altså ikke, at immigranter ikke havde travlt med at komme til Moskva).

2. Russiske mænds forventede levealder var 66 år, og selv om det er katastrofalt lavt for et land som Rusland, så var der tale om en stigning på 7-8 år inden for de seneste 20 år, og tendensen ser ud til at fortsætte. (Det var altså forkert, når Obama sagde, at den forventede levealder var 60 år).

3. Rusland er stadig verdens næststørste våbeneksportør inklusive hightech, og som noget nyt er Rusland blevet en supermagt inden for eksport af fødevarer (20 mia. dollars i 2017), Rusland er nr. 1 i verden inden for eksport af atomkraftværker og Ruslands svar på Google, Yandex, har produceret en søgemaskine, der er den fjerde eller femte største i verden (Det stemmer altså ikke, når Obama siger, at Rusland ikke producerer noget, om end proportionerne er nogle andre end for USA's vedkommende).

4. Endelig er den russiske befolkning steget hvert år siden 2008, om end den vil falde $\mathrm{i}$ år og de kommende år. (Det var med andre ord forkert, når Obama i 2014 sagde, at den russiske befolkning skrumper.) Udviklingen sættes i relief, hvis man sammenligner Rusland med de baltiske lande samt $\emptyset$ st- og Centraleuropa, hvor der i nogle tilfælde er tale om befolkningsfald på 15 pct. inden for de seneste 20-25 år.
I sit svar gentog Obama forestillinger, som er udbredt i Europa og Nordamerika. De florerer i medierne og i den offentlige debat, men de stemmer ikke med virkeligheden. Når en amerikansk præsident, som man må forvente er blevet briefet før et interview, kan begå fire faktuelle fejl i fire sætninger om Rusland, hvordan forholder det sig mon så med alle os andre?

De seneste årtiers kognitionsforskning har vist, at vi er drevet af en lang række bias, når vi ser på verden og forsøger at forstå den. Vi ser ikke verden, som den er, men som vi forventer, at den skal være. Vi lægger mere vægt på negative nyheder end på positive, og vi har en tilbøjelighed til at tro, at de ting, der først dukker op i vores bevidsthed, når vi skal analysere en begivenhed eller en tendens, forekommer hyppigere og derfor er sand.

Tag et fænomen som tornadoer i USA. De bliver væg-til-væg dækket af medierne, når de rammer. Også i Danmark i øvrigt. Derfor tror et flertal af amerikanere, at tornadoer er en hyppigere dødsårsag end astma, selv om tornadoer om året blot koster omkring 50 amerikanere livet, mens 80 gange så mange, altså 4.000 mennesker, dør af astma.

Påstanden om, at Rusland er en benzinstation forklædt som et land (John McCain), altså at Rusland alene lever af olie og gas, bekræfter vores paratbillede, og det vi normalt hører i medierne. De færreste ved, at den russiske økonomi de seneste fire år er blevet mindre afhængig af indtægter fra olie og gas. I 2014 krævede det russiske statsbudget en oliepris på 98 dollar 
pr. tønde for ikke at gå i minus, mens prisen i 2018 er nede på 53 dollar, altså næsten en halvering i forhold til for fire år siden, og med en aktuel oliepris på 81 dollar ser det ud til, at man i år kommer ud med et overskud på 1,5-2 pct. af BNP på statsbudgettet på trods af sanktioner og alvorlige strukturelle problemer i økonomien (korruption, statens dominerende rolle, alt for lave vækstrater og meget andet).

Hvis man abonnerer på en bestemt ideologi og deler verden op i stammer, hvor nogle er venner, og andre er fjender, vil man være tilbøjelig til at lægge mærke til alt det hos ens egen stamme og hos fjenden, der bekræfter ens verdensbillede, mens alt det, der peger i andre retninger, vil blive filtreret fra. Det er i ekstrem grad tilfældet med Rusland. Hvad kan vi gøre for at frigøre os af de fordomme, der hæmmer vores evne til at se verden, som den er? Ifølge den amerikanske kognitionsforsker Steven Pinker bør vi anstrenge os for at tænke kvantitativt, dvs. empirisk, se på data og statistikker, og ikke tro for meget på gode historier og anekdoter.

Statistikker og data gør det imidlertid ikke alene. Kontekst er også vigtig. De samme fakta kan ofte udlægges på forskellig vis. På den ene side kan man med tal i hånden konstatere, at den globale fattigdom i løbet af de seneste 200 år er blevet reduceret fra 90 pct. til blot 10 pct. blandt verdens befolkning. En fantastisk udvikling, der er grund til at glæde sig over. Men man kan også på baggrund af den samme statistik sige, at flere end 700 mio. mennesker på kloden i dag lever i fattigdom. En situation som giver grund til bekymring. Med udgangspunkt i data og statistikker vil jeg i de næste klummer faktatjekke de påstande af Obama, som jeg citerede ovenfor, og se på andre ting, der udfordrer det gængse billede af Rusland. Det handler ikke om at være for eller imod Putin, om Rusland er en trussel og i hvilket omfang. Nej, det handler om at basere vurderinger og analyser på data, ikke på myter og fordomme.

Eksempel: Vi foretrækker at se Rusland som tilbagestående, brutalt og ineffektivt, for sådan skal et antivestligt og autoritært regime se ud for at stemme med vores forståelse af verden. Der er da også noget om snakken, men det hører med til billedet, at Rusland siden 1998 ifølge the Spectator Index er den økonomi i Europa, der har haft den største vækst i sit bruttonationalprodukt beregnet i forhold til købekraft, nemlig 216 pct. På de næste pladser følger Polen (203 pct.), Irland (201 pct.), Tyrkiet (173 pct.) og Ungarn (141 pct.) Danmark rangerer ikke blandt de øverste 18.

\section{Søren Liborius}

"I Rusland er det godt, at det går bedre end i 90'erne. Det ville dog voere bedre, hvis det gik godt."

(replik i Berlingske 23. oktober 2018) Flemming, jeg skrev en replik primært for at adressere Berlingskes rettelse: “... Ifølge tilgæengelige data fra World Bank og IMF har den russiske veekst $i$ perioden siden 2016 veret blandt de største i Europa, men ikke størst " og for at påpege, at jeg ikke tilhører dem, 
der forventer, endsige ønsker, et Rusland i økonomisk kollaps.

Jeg ville ikke skamride vinklen med The Spectator Index (som jo viste sig at være et russisk fake-news-site), men kunne ikke sidde overhørig påstanden om, at Rusland skulle have været der, hvor væksten havde været 'blandt de største i Europa siden 2016', idet jeg husker, at netop i 2016 var der negativ vækst i Rusland (olieprisfald), mens resten af Europa buldrede derudaf, og væksten i 2017 var klart under Europa/EU-niveau.

Det påviste jeg med bl.a. IMF- og Verdensbank-tal. (Jeg kan huske, vi under en samtale i Moskva sommeren 2016; du var vist på vej til eller fra Valdai, netop drøftede de russiske $\varnothing$ konomers dystre varsel om, at stabilitets- og velfærdsfondene ville blive tømt til inden for 12-18 måneder, hvis ikke olieprisen steg. Og kun takket være enorm opbremsning i import og kraftige sociale nedskæringer holdt man skindet på næsen mht. handelsbalance og budgetunderskud.)

I replikken ville jeg også gerne problematisere det mærkværdige forhold, at væksten aftog systematisk i Rusland fra 2011, og faldet accelereredes fra 2012 til 2015. Det på trods af rekordhøje priser på Ruslands vigtigste produkt, olie, med priser på 110-115 dollar i alle årene! Mens Kina og den $\varnothing$ vrige verden buldrede derudaf og efterspurgte russiske råvarer, svækkedes den generelle vækst i Rusland for endelig at blive negativ i 2016. Hvordan i alverden kan det forekomme?

Det er i mine øjne den tydeligste illustration af noget rivende galt i funktionsmåden af økonomien; transmissionsmekanismen til investeringer virker simpelthen ikke. De offentlige anlægsarbejder er rekorddyre på grund af returkommission, korruption, ufri konkurrence osv. Eller penge forsvinder blot ud af landet ad lyssky/ kriminelle kanaler til personlig berigelse. Det koster i absolutte tal ca. dobbelt så meget at bygge en standardkilometer vej i Rusland som i Danmark.

Jeg anser desværre, at Rusland i dag i stigende grad er blevet et kleptokrati med mafiøs, snæver fordeling af godbidderne, herunder hvem der skal nyde godt af den protektionisme, som reelt er indholdet i de russiske 'modsanktioner'. Mange russiske landbrugsrestriktioner og importforbud imod EU-lande var i kraft inden Krim- og Østukraine-sanktionsvæsenet begyndte. Systemer med kvote- og priskorridorer i forhold til $\mathrm{fx}$ de såkaldte partnere i EAEU, Eurasian Economic Union; i øvrigt den første økonomiske integrationsmekanisme, hvor samhandelsvolumen faldt siden indgåelsen af aftalerne. Ret tankevækkende.

Vi kan godt blive enige om, at Rusland kan sælge atomkraftværker (skyldes især det relativt simple design og ROSATOM, der som statsvirksomhed og leverandør af Ruslands egen A-kraftværker ikke tillades at gå konkurs som andre kommercielle aktører og kan byde på mere usikre kontrakter). Men fraset våben, som det eneste forædlede industriprodukt, udgør råvarer mindst 80 pct. af russisk eksport. Dermed bliver det interessante jo, om der kan skabes rum for iværksætteri 
og små-og mellemstore virksomheder. Det forudsætter en helt anden juridisk kultur og erhvervslovgivning. Det er desværre entydigt gået tilbage og resultatet: en stadig større rolle for store statslige virksomheder, som malkes af 'vennerne'.

Er Rusland en supermagt inden for eksport af fødevarer? Nej. Det vil formentlig overraske, men faktisk eksporterer Danmark for mere end Rusland. Danmarks fødevareeksport har højere værdi end Ruslands. Men hverken Danmark eller Rusland er i international top-20. Rusland eksporterer især uforarbejdet hvede og rangerer med sin 20 mia. dollareksport lige efter Danmark, der med vor eksport på ca. 22 mia. (2017-værdi) er rangordnet som verdens 22 . største eksportør. Rusland er således nr. 23 jf: https:// www.worldatlas.com/articles/the-american-food-giant-the-largest-exporterof-food-in-the-world.html og https:// globalnyt.dk/content/dansk-foedevareeksport-slog-rekord-i-2017.

Det bringer mig tilbage til mit hovedærinde, nemlig hvorfor Rusland ikke er blandt verdens top-10 eller top-5? Rusland er det eneste område på den nordlige halvkugle, hvor landbrugsproduktion kan skaleres op i stor skala ved at opdyrke nye store arealer eller intensivere eksisterende produktion. Landet har en århundredlang forskningstradition, men det er svært at finde en rigtig landmand med følelse for dyrene og jorden. Man finder derimod masser af 'samlebåndsarbejdere' på landet. Landbruget udvikler sig kun langsomt, mens de østeuropæiske lande har taget stormskridt. Jo, danske grisebønder har vellykkede investeringer, men på 18 år burde Putin jo have bragt Rusland i top-5.

$\mathrm{Nu}$ vi er ved størrelse og handelsforhold. Som jeg skrev i mit indlæg: Tag et gæt: var EU's økonomi i 2017 dobbelt så stor som Ruslands? Fem gange så stor? Eller mere end 11 gange så stor? Ja, mere end 11 gange. I tal er EU's økonomi 18,77 tusinde mia. dollar værd mod Ruslands 1,58 tusind mia. ifølge IMF.

Størrelse er vigtig, fordi Rusland har det bedste marked og den bedste nabo, det kan tænke sig. I EU har man en udviklet, velstående og fredelig økonomi, der efterspørger russiske produkter, og som tilmed er den største investor i Rusland. Derfor er det foruroligende, især for Rusland selv, at Kreml synes at vælge den evindelige konfrontation frem for samarbejde.

Med Ruslands naturressourcer burde landet faktisk have et velstandsniveau på linje med Norge. Rusland og EU er naturlige økonomiske partnere; vi konkurrerer ikke om det samme, vi er hinandens bedste handelspartnere. Hvorimod EU og Kina vil være konkurrenter i næsten alle forhold. Vi konkurrerer om de samme naturressourcer.

Jeg er dog enig med dig, Flemming, $i$, at Vestens økonomiske system ikke er det eneste saliggørende for alle lande på kloden. Det er også en spændende diskussion.

\section{Flemming Rose}

Tak for din grundige forklaring. Jeg har selvfølgelig ikke talt om perioden siden 2016, hvor det står skidt til (det 
skrev jeg også i min klumme), selv om vi ikke har oplevet noget sammenbrud for den russiske økonomi som Economist og Time Magazine forudså tilbage i $2014 / 15$.

Rusland er makroøkonomisk velkonsolideret. Martin Gilman, tidligere IMF-direktør i Rusland, mener, at den russiske regering har ført verdens bedste makroøkonomiske politik i en ekstremt vanskelig situation. Valutareserverne er på niveau med før krisen $(460$ mia. dollar), overskuddet på statsbudgettet nærmer sig 2-2,5 pct. af BNP (et gigantisk beløb), og statsgælden er omkring 15 pct. af BNP - alt sammen tal der indebærer, at Rusland kan finansiere sin import i 17 måneder, uanset hvad der sker, om så der bliver lukket og slukket for det varme vand alle steder. Handelsbalancen ser $i$ år ud til at blive den bedste i mange år, i nærheden af 120 mia. dollar. Det er den stik modsatte situation af 1991 og 1998.

Igen, det betyder ikke at det går strålende, men det er data, der er nødvendige for at forstå det samlede billede, og hvorfor landet ikke befinder sig på randen af sammenbrud eller oprør. Det er også vigtigt, at Rusland i de forgangne fire år har gjort, hvad man kunne for at blive mindre afhængig af internationale konjunkturer. Det betyder lavere vækst og mindre dynamik, men mindre risiko for de helt store chok. Med Rusland går det aldrig så godt som optimisterne håber, og aldrig så skidt som pessimisterne forudsiger.

Jeg talte om perioden siden 1998. Det rigtigste ville have været at tage 1999, da det var det år, Putin kom til magten; nogle har kritiseret mig for at tage 1998 som lavpunktet for russisk $\varnothing$ konomi, og det er en fair kommentar, men i forhold til hele Putins periode er 1999 altså relevant. I øvrigt interessant at ingen brokker sig, når man tager lavpunktet for det russiske forsvarsbudget som udgangspunkt for en kommentar om, hvor voldsomt det er vokset, mens det i forhold til BNP ser helt anderledes ud, hvis man tager 1992 - altså det nye Ruslands første år, da alt mellem Moskva og Vesten var fryd og gammen, sådan da.

Angående olieprisen, rent seeking, korruption, hvidvask og alt andet godt fra havet så er det russisk økonomis akilleshæl, men også her er der sket enkelte forandringer, som jeg nævnte i min klumme. I 2013 balancerede det russiske budget med en oliepris på 114 dollar pr. tønde, i dag er det 53 dollar, for få år siden tegnede olie og gas sig for over 60 pct. af indtægterne i statsbudgettet, $\mathrm{i}$ begyndelsen af året var det 40 pct. (nu er det steget igen, fordi olieprisen er så høj).

Det skyldes ikke kun, at man har beskåret budgettet med 50 pct., det hænger også sammen med, at man har fundet andre vækstpunkter i økonomien, fødevarer og kemikalier fx.

Siden indførelsen af sanktioner er kapitalflugten mindsket (godt for Putin, om end den i sidste kvartal af 2018 er steget igen), og rige russere har flyttet flere penge tilbage til Rusland, hvad Putin har forsøgt på i mange år, men aldrig er lykkedes med. Dermed ikke være sagt at sanktioner ikke er berettigede, de har bare også haft nogle utilsigtede effekter, som er 
modsat hensigten med dem. Sat på spidsen kan man sige, at de foreløbig har styrket Putin, men svækket Rusland. Det samme gælder den eksplosive vækst i fødevareeksport, og at russisk økonomi i det hele taget er blevet mindre følsom over for, hvad der sker uden for landet.

Hvidvask og korruption gælder hele det tidligere Sovjetunionen (minus Baltikum og måske Georgien), ikke kun Rusland. En frisk meningsmåling fra Ukraine viser, at ukrainerne mener, at deres egen regering er et større problem end den russiske krigsførelse, og så forudsætter det villige samarbejdsrelationer i Vesten. Bank of New York i 1999 eller aktuelt Danske Bank er ikke russisk hvidvaskning. Det er vestlige bankers hvidvaskning af russiske og andre tidligere sovjetrepublikkers penge. Det betyder, at løsningen ikke skal findes i Rusland, men hos os selv.

Alle de problemer, du anfører, $S \varnothing$ ren, er relevante og to the point, men jeg tror, at Rusland kan 'muddle through' i lang, lang tid, og jeg synes, at vi skal gå tilbage og tjekke vores egne forudsigelser for 5-10-15 år siden og så se, hvordan virkeligheden ser ud. Konklusionen på den øvelse vil være, at politikere, medier og andre meningsdannere har stået i $\mathrm{k} \varnothing$ for at forudsige Ruslands snarlige sammenbrud, men uanset hvor skidt det er gået, så er det ikke sket.

Hvorfor er det ikke sket? Hvad er det, vi ikke har været opmærksomme på? Ja, det går ikke prangende, men det går altså heller ikke så skidt, som mange seriøse vestlige iagttage- re forudså, og hvis man sammenligner dagens Rusland med det land, jeg ankom til i 1990 som korrespondent, så er det altså på mange måder et helt andet land.

\section{Søren Liborius}

Lad mig også kvittere for dit grundige svar. Jeg ser, at vi egentlig er ganske enige om, at Rusland hverken stod eller står på randen af kollaps og kan 'muddle through'.

Jeg vil gerne knytte et par kommentarer til den diskussion, vi førte, da vi mødtes i Moskva i 2014. Såfremt fondene var blevet tømt dengang, var gældsbelastningen relativt lille, og muligheden for at gå videre med låneoptag bestemt tilstede. Noget som man jo også havde tyet til året forinden. Samtidig var (og er) statslige virksomheder, der bærer hovedparten af de internationale gældsforpligtelser i Rusland, i stand til at finansiere det med virksomhedsobligationer.

Meeeeen, med de seneste målrettede sanktionstiltag bliver det interessant, om virksomhederne i fremtiden kan rejse kapital. Oleg Deripaska er det seneste tydelige eksempel på, at der kan vise sig ganske store problemer. Jeg hører fra min kilder i den russiske Centralbank, at deres kinesiske kolleger er mere tøvende end før med at låne. Og det som ikke har vist sig endnu - og har potentiale til at belaste både cash flow og kreditbeholdning hos staten - er, om virksomhederne en bloc henvender sig til staten som 'lender of last resort.'

Jeg har tidligere i andre sammenhænge udtalt, at en af konsekvenserne 
af sanktionerne formentlig er, at den russiske stat vil ende med endnu større ejerandel af virksomheder, der enten er på vej i stagnation eller blot behøver meget kapital for at udvikle sig.

Vi er også enige om, at Putin har opnået øget opbakning ved at kunne fremstille sanktioner som udlandets kamp mod alle russere. Jeg mener, at den fortælling begynder at svækkes, og at der skal stedse 'hårdere narkotika' til i form af skinger propaganda for at fastholde befolkningen i den fortælling. Bieffekt: det skræmmer investorer bort.

Nuvel, så længe det statslige budget er blevet så beskåret, hvilket vi jo begge påpeger, og oliepriserne er høje ja, så kan man 'muddle through'.

Dermed er vi jo faktisk også enige om, at råstoffer og især energipriser er og forbliver 'key lever' i russisk økonomi. Et vue over de seneste år viser tydeligt dette.

Ja, handelsbalancen viser kraftigt overskud, men det hører også med, at det skyldes kraftig importopbremsning, som viser sig i underinvestering, som igen viser sig $i$ en faldende produktivitet, der i forvejen lå blandt de laveste i Europa. Alt sættes, om ikke på vågeblus, så voldsomt ned i gear i forhold til, hvad der egentlig skulle forventes. Rusland burde faktisk være et slags 'kæmpe-Polen' blot også med olie/gas.

Bestemt, samfundet er jo et helt andet end i 90'erne - det er vi helt enige om. Jo, hvedeeksporten er det, som driver russisk landbrugseksport. Det skal nok fortsætte, når klodens munde skal mættes. Men det kan altså ikke være et sundhedstegn i økonomien, at svineproducenter og landbrugsoligarker næsten selv kan bestemme prisen på deres varer, fordi de har lobbyet hårde importforbud, eller at bil- og lastvognsproducenter tvinges til at samle, adskille og importere og gensamle produkter til det russiske marked med det resultat at stk-prisen går 20 pct. op. Eller at statslige jernbaner 'over-night' tillades prisstigninger på 20-30 pct., mens man vil promovere sig som Asien-Europa link.

Et andet interessant kapitel er befolkningens forventninger: regionalt, i de store byer, og i forskellige aldersgrupper. Den diskussion viser mange forskelligrettede tendenser, som det kunne være godt at drøfte. 'Brain drain' eller hvad? Mange højtuddannede forlader Rusland, men pålidelig statistik er vanskelig at få fat $i$, så det bliver mere baseret på lønniveauer for specialister og på anekdotiske beskrivelser. Men i kortform er mit synspunkt: man skal ikke forvente 'revolution rundt om hjørnet'. Reformpresset er dæmpet fra en befolkning, som i stigende grad er 'disenfranchised' eller skræmt fra kritisk deltagelse.

Jeg mener, at den markant strammere generelle kontrol siden 2012-demonstrationerne har negativ indflydelse på russisk økonomi. Det kommer bl.a. til udtryk ved de allestedsnærværende myndigheder, som under dække af skatteinspektion, brandkontrol, sundhedstjek osv. ligger på lur for at hapse attraktive virksomheder. Man bør også diskutere apati og frygt. Jeg anser, at det er markant mere til stede end før 2012. 'Muddle through' dæk- 
ker nok også over, at befolkningen, fraset en 'city-boble' inden for de fire-fem største millionbyer, er fastholdt i sociale standarder, der nærmest ligner armod, langt under, hvad man kunne forvente sig.

Du bragte IT-sektoren på banen; Pavel Durov (VKontakte) valgte jo at forlade (flygte fra) Rusland, og så store er de andre aktører vel ikke. Foruden at have en hjemmemarkeds- og russisk sprogfordel, så kan jeg ikke umiddelbart se hvilke russiske IT-produkter/koncerner, der har iøjnefaldende succes internationalt, læs uden for det russiske sprogområde.

Med hensyn til industri tror jeg snarere, at et tydeligt eksempel på dagens russiske industriudvikling er fx Sukhoi's civilfly; deres flagskibssatsning på regionale Sukhoi Superjet 100 passagerfly. Men de højtspecialiserede fly er sammensat af dele, der for betydelige komponenters vedkommende ikke er russiske, men enten europæiske eller amerikanske. (http://www.aeronewstv. com/en/industry/commercial-aviation/3748-building-a-sukhoi-superjet-100-who-does-what.html)

Desuden er mange projekter udformet som joint ventures for at sikre teknologiadgang, og selvom den russiske metalindustri spiller en vigtig rolle, er projekterne helt afhængige af statslige subsidier og 'købrussisk'-klausuler (Aeroflot er pålagt at købe dem), og dets kommercielle fremtid er ikke sikker.

Er alt dette godt eller dårligt? Det viser $i$ alle fald nytten af international arbejdsdeling og modsiger Kremls $\varnothing$ vrige betoning med selvforsyning.
Samtidig er det dog tankevækkende, at den ellers gigantiske sovjetiske flyog rumindustris aftagere burde være en mere fremtrædende leverand $\varnothing \mathrm{r}$ af komponenter. Men de små og mellemstore specialiserede virksomheder er blevet opslugt af 'de fede katte' ganske som det er sket i det russiske statslige United Shipbuilding.

Nu skal dette ikke være et defensorat for, at 'alt er ringe i Rusland', og jeg synes egentlig ikke, at billedet $\mathrm{i}$ Danmark har været, at 'Ruslands står på fallittens rand'. Danske medier valgte klogt atter at sende flere korrespondenter til Rusland, så det ikke kun var Simon Kruse. De har da bidraget til et nuanceret billede. Om det så er rumeventyr med Peter Mogensen, optakt til foldbold-VM, reportager fra rundt i landet; a la 'mød en købmand i Kursk', DR P1's jævnlige, længere reportager osv.

Lad mig for god orden skyld også slå fast, at jeg ikke tilhører dem, der forventer Ruslands snarlige økonomiske kollaps. Jeg ønsker det ej heller. Det ville være sørgeligt for mange fredelige russere, og det kunne skabe farlige situationer. Jeg har også arbejdet $\mathrm{i}$ mange år for at udvikle vores samhandel og investeringer mellem Danmark, EU og Rusland ud fra antagelsen, at et udviklet, stabilt Rusland i fred med sig selv og sine naboer er en bedre nabo i Europa end et fattigt, forarmet, desperat Rusland med bl.a. kernevåben til fals for forskellige grupper.

Lad mig også fastslå, at de internationale sanktioner, indført i 2014 efter erobringen af Krim og krigen i Østukraine, ikke havde til formål at 
knække Rusland økonomisk. Sanktionernes sigte var mere smalt.

Rusland afgør selv sin fremtid. Vi har ikke noget ønske om at 'belære' som i 1990'erne. Rusland er i dag et samfund i søgen efter sin fremtid. Putin har erkendt, at den nuværende $\varnothing$ konomiske model baseret på råstoffer har nået enden. Hvordan skal den reformeres? Samtidig afstår man dog fra at tage afgørende skridt til at stimulere nye sektorer og det er trist.

\section{Flemming Rose}

Jeg tror ikke, vi er uenige, jeg har i hvert fald ingen indvendinger imod din analyse.

Jeg tror, det handler om, hvad man vælger at fokusere på, og om glasset er halvt fuldt eller halvt tomt, helt fuldt eller helt tomt. Hvad skal vi sammenligne med? Sovjetunionen, Rusland i 1990'erne eller 00'erne? Vesteuropa og USA? Polen og Norge eller Tyrkiet og Ukraine? Levadas tilfredsbarometer viser faktisk, at 45-55 pct. af russerne mener, at landet er på rette vej. Da Putin kom til, var det 10-12 pct. Det er bedre end i de fleste vestlige lande og kan ikke forklares alene med propaganda og strammere kontrol.

For øjeblikket er propagandaen ikke på niveau med 2014-2015. Det lykkedes for nylig det Kreml-kritiske magasin New Times at indsamle 27 mio. rubler fra 13.000 forskellige bidragydere for at betale en helt urimelig bøde. Det er et tegn på, at der findes et civilsamfund. Jeg oplevede noget til- svarende, da jeg for nylig talte til 1.500 liberale i Moskva om ytringsfrihed. De virkede ikke skræmte eller parate til at bøje sig for Kremls vilje.

Jeg vil sammenfatte det på denne måde: Det går ikke godt for russisk $ø$ konomi, væksten er lavere end det globale gennemsnit, og der er store strukturelle udfordringer, men det går ikke så skidt, som de fleste forudså efter indførelsen af sanktioner og faldende oliepriser i 2014. Det var min pointe.

Den helt store udfordring på lidt længere sigt - hvis sanktionerne fortsætter eller skærpes - bliver håndteringen af manglende teknologioverførsel fra Vesten med alt, hvad det indebærer af lav produktivitet og manglende diversificering af økonomien.

En enkelt ting til den digitale teknologi. Yandex har stor succes, det er verdens fjerde eller femte største søgemaskine, og de har et marked i Ukraine og Tyrkiet. Det samme gælder datasikkerhedsgiganten Kaspersky Lab., selv om de har fået problemer nu grundet deres påståede forbindelse til efterretningstjenesten. Og ja, her bør også nævnes VKontakte og Telegram, selvom de er sat i søen af en russer, der er gået i eksil.

I det hele taget er de russiske myndigheder inspireret af kinesernes satsning på digital teknologi som et instrument til mere effektiv regeringsførelse og bedre kontrol med borgere og politiske processer. 